\title{
Family of Soft-Switched PWM Converters with Minimized Auxiliary Switch Time
}

\author{
Gyubum Joung ${ }^{1}$, Zhiyong Dong ${ }^{2}$, Sejong Hwang ${ }^{3}$ and Dong-Gyu Jeong* \\ ${ }^{1}$ Professor, Dept. of Energy Engineering, Woosuk University \\ ${ }^{2}$ MS Student, Dept. of advanced Materials Engineering Woosuk University \\ ${ }^{3}$ MS Student, Dept. of Elecrical and Electronics Engineering Woosuk University \\ "Professor, Dept. of Elecrical and Electronics Engineering Woosuk University \\ 'gbjoung@woosuk.ac.kr, ${ }^{*} j d g @ w o o s u k . a c . k r$
}

\begin{abstract}
In this paper, we propose a family of soft-switched pulse-width modulation (PWM) converters with main and auxiliary switches that turn on at zero current and off at zero voltage. To generalize the soft-switched PWM converters, two types of auxiliary cells are suggested. They have two saturable inductors, which are operated to reduce the reverse recovery current of the diodes and to minimize the effective on time of the auxiliary switch. The switching losses of converter switches are very low on account of soft switching. Moreover, the auxiliary switch conduction loss is minimized by reducing the auxiliary switch conduction time. By applying a boost-type converter, the converter is analyzed and its characteristics are considered. The characteristics are verified by experimental results for a $250-\mathrm{kHz}$ operation for the boost-type converter. The experimental result shows that the auxiliary switch pulse width is approximately 1/20 of the main switch for the half-duty ratio of the $250-\mathrm{kHz}$ operation. This result is better than the conventional one at same condition.
\end{abstract}

Keywords: DC-DC converter, power supply, soft switching converter, high efficiency converter, high frequency converter

\section{Introduction}

Owing to their simple topologies and basic pulse-width modulation (PWM) control, PWM converters have been widely used for converter applications. Meanwhile, the highpower density converter has been very attractive for portable systems and aerospace applications. To reduce the converter system size and weight, high-frequency switching with low switching loss is required. Reducing these switching losses, soft switched converter has been employed [1-8].

Resonant converters have researched for reducing switching losses [1, 4]. Nevertheless, the conduction losses for resonant converters are higher than those of conventional PWM converters on account of their resonant operations. Reduction of switching losses and conduction losses of the main converters switches have resolved for high-power density systems. Consequently, soft-switched PWM converters have been studied [2,3,5-8]. Because the soft switching of PWM converters has minimized switching losses, the converters generally have a high efficiency at high-frequency operations. However, these kinds of systems have been operated at the hard switching turn-off for auxiliary switches. This increases both the switching loss of the auxiliary switch and the noise of the converter.

To obtain soft switching of the auxiliary switch, a soft-switched PWM converter that operates at a fixed frequency has been researched. The main and auxiliary switches of the

Received (June 18, 2017), Review Result (August 24, 2017), Accepted (September 5, 2017) 
converter are softly switched at zero voltage and/or zero current conditions. However, a portion of the conduction period for the auxiliary switch is increased at a higher operating frequency. The turn-on conduction ratio between the auxiliary and main switches ranges from approximately one-fifth to one-tenth for $250 \mathrm{kHz}$ [8].

In this paper we propose a family of soft-switched PWM converters with main and auxiliary switches that turn on at zero current and off at zero voltage. The pulse width of the auxiliary switch conduction period is minimized in these converters. To generalize the converters, two types of auxiliary cells are suggested. They have two saturable inductors, to reduce the reverse recovery effects of the diodes while satisfying the zero current turnon of the switches. To reduce the turn-on time of the auxiliary switch, the resonant operation of the converter is omitted. Because there is no resonant operation, the effective pulse width of the conduction current of the auxiliary switch can be reduced to as low as 100 nsec. In an evaluation, the converter was applied to a PWM boost converter, which always satisfies the soft switching of main and auxiliary switches.

\section{Soft-Switched PWM Converter}

\subsection{Converter Operation}

Figure 1 shows the circuit of the soft-switched PWM boost converter.

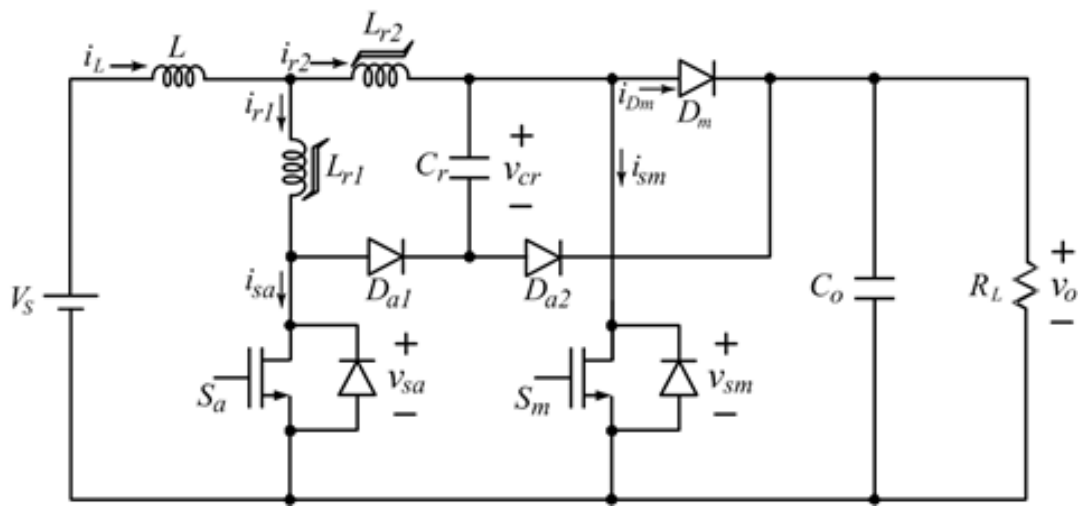

Figure 1. Proposed Soft-Switched PWM Boost Converter

The basic configuration of this converter is similar that of the conventional PWM boost converter. The proposed converter additionally has two diodes, an auxiliary switch and small ratings of two saturable inductors and a capacitor. In this converter, the main topology is the same as that of the conventional soft-switched converter. To reduce the auxiliary switch conduction time, the conventional converter changes the circuit [8]. In this paper, on the other hand, a different switching pattern is suggested to obtain the minimized conduction time of the auxiliary switch.

\subsection{Converter Switching}

The switching operation of the converter is divided into six modes, as shown in Figure 2. The typical waveform of the soft-switched PWM converter is shown in Figure 3. In modes 0 and 4 of Figure 2, the switching of the main switch is similar to that of the conventional PWM converter. The main switch has a turn-on process during modes 1 through 3 , and a turn-off process during mode 5 . In this analysis, the inductor current, $i_{L}$, and output voltage, $v_{0}$, are assumed to be constant values, which are $I_{L}$ and $V_{0}$ respectively.

The descriptions of the modes are summarized as follows. The turn-off switching is the same as that of the conventional zero-voltage-switching (ZVS) PWM converter[8]. 
However, to reduce the conduction time of the auxiliary switch, the turn-on process differs from that of the conventional ZVS PWM converter. Summaries of the modes for the suggested switching pattern are presented below. Waveforms for the converter modes are shown in Figure 3.

(1) Mode $0\left(t_{0-} t_{1 a}\right)$ : The main diode, $D_{m}$, is conducting and all other switches are turned off, as shown in Figure 2 (a). Therefore, the inductor current, $i_{L}$, is transferred to the load through the saturable inductor, $L_{\mathrm{r} 2}$, and main diode, $D_{m}$. In this mode, the saturable inductor current, $i_{r 1}$, remains zero, and $i_{r 2}$ is equal to $I_{L}$. The main switch voltage, $v_{s m}$, continues to be $V_{0}$.

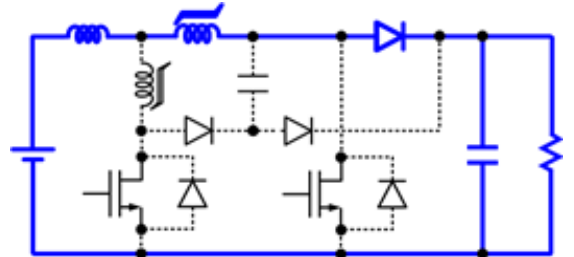

(a)

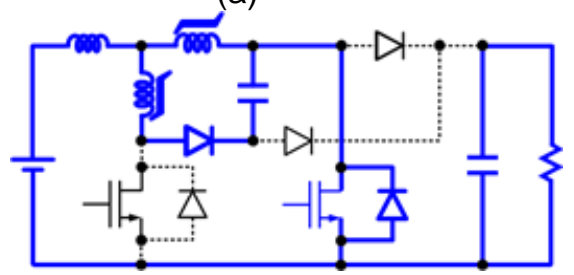

(c)

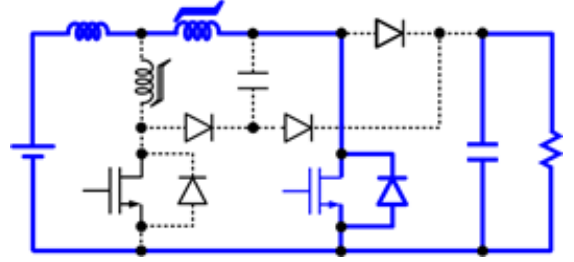

(e)

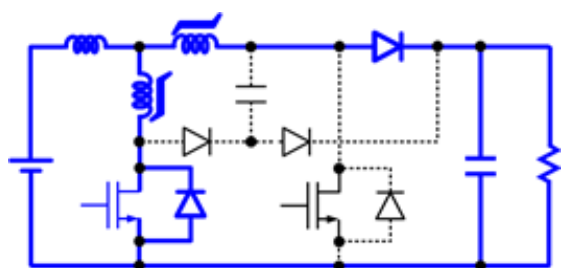

(b)

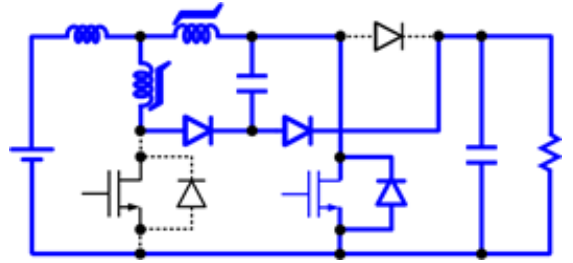

(d)

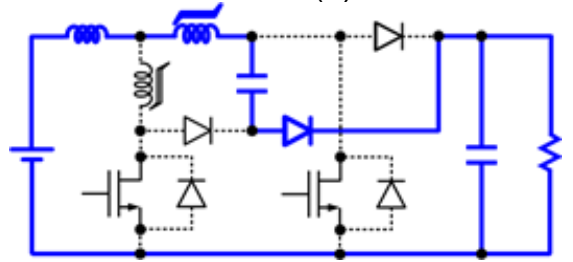

(f)

Figure 2. Switching Operation of Converter with Six Modes 


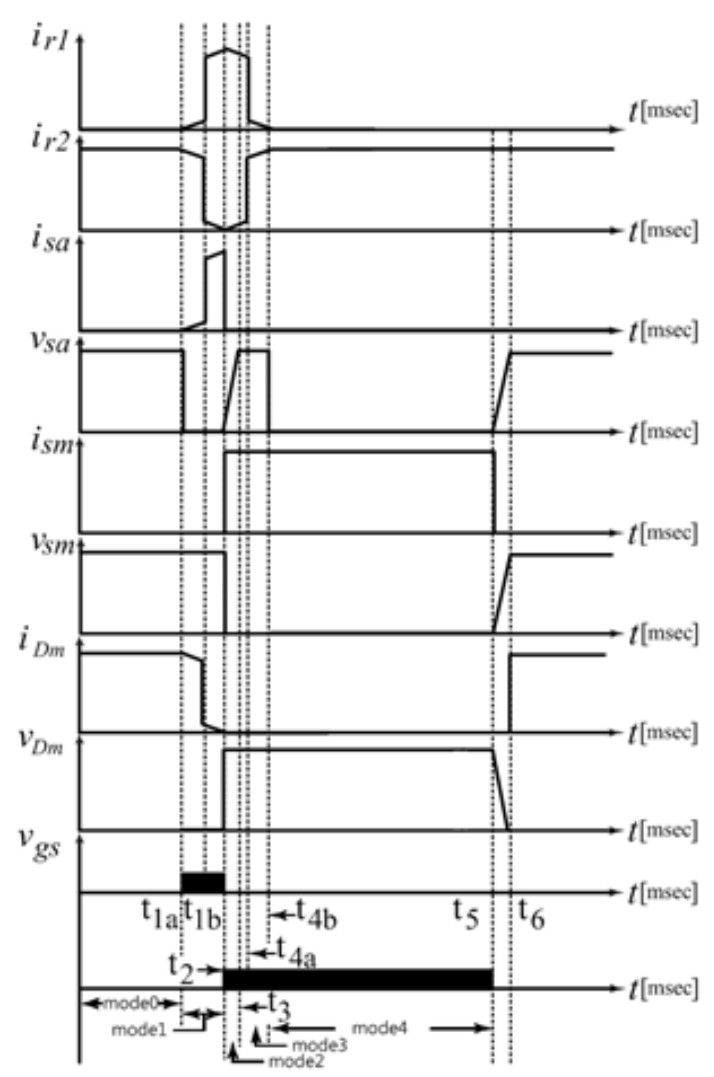

Figure 3. Switching Waveform of Converter

(2) Mode $1\left(t_{1 a}-t_{2}\right)$ : This mode is divided into two parts as outlined below.

(a) $\left(t_{1 \mathrm{a}}-t_{1 b}\right)$ : To turn on the main switch, $S_{m}$, mode 1 starts when the auxiliary switch, $\mathrm{S}_{\mathrm{a}}$, triggers at time $\mathrm{t}_{1 \mathrm{a}}$. The saturable inductor current, $i_{r 2}$, is increased by the following rate until $i_{r 2}$ is saturated.

$$
\frac{d i_{r 1}}{d t}=-\frac{V_{\mathrm{O}}}{L_{r 1}}
$$

Therefore, the current slope of the auxiliary switch, $S_{a}$, is the rate of equation (1).

(b) $\left(\mathrm{t}_{1 \mathrm{~b}}-\mathrm{t}_{2}\right)$ : When the saturable inductor, $L_{r 1}$, saturates, the current of $i_{r 1}$ is abruptly increased until $L_{\mathrm{r} 2}$ becomes unsaturated. After $L_{\mathrm{r} 2}$ is unsaturated, the currents of $i_{r 1}$ and $i_{r 2}$ are respectively increased and decreased by the rate of equation (2). They are:

$$
\frac{d i_{r 2}}{d t}=-\frac{d i_{r 1}}{d t}=-\frac{V_{\mathrm{O}}}{L_{r 2}}
$$

(3) Mode $2\left(t_{2}-t_{3}\right)$ : When $i_{r 1}$ reaches $I_{L} I_{L}$ at $t_{2}$, the main diode current is decreased to zero. The slope of the reverse recovery current for the main diode, $\mathrm{D}_{\mathrm{m}}$, is limited by the slope of equation (2). Mode 2 begins when the main switch, $\mathrm{S}_{\mathrm{m}}$, is triggered on and the auxiliary switch, $S_{a}$, is triggered off at $t_{2}$ as shown in Figure 3 . Therefore, no resonant operation occurs during the turn-on process of the main switch $\mathrm{S}_{\mathrm{m}}$. Practically, the period between the turn-on of $\mathrm{S}_{\mathrm{m}}$ and turn-off of $\mathrm{S}_{\mathrm{a}}$ can be overlapped to prevent all main and auxiliary switches from turning off. Therefore, the main switch, $\mathrm{S}_{\mathrm{m}}$, can satisfy the zero current turn-on by overlapping on times of $\mathrm{S}_{\mathrm{m}}$ and $\mathrm{S}_{\mathrm{a}}$. In this mode the energies of the saturable inductors are transferred to the capacitor, $C_{r}$, until the capacitor voltage reaches the output voltage, $V_{O}$. In this mode, the voltage of the capacitor, $C_{r}$, should be increased by the following rate: 
$\frac{d v_{c r}}{d t}=\frac{I_{L}}{C_{r}}$

Thus the turn-off slope of the auxiliary switch, $\mathrm{S}_{\mathrm{a}}$, is represented by equation (3).

(4) Mode $3\left(t_{3}-t_{4 b}\right)$ : When the capacitor voltage of $C_{r}$ is increased to the output voltage, $V_{\mathrm{O}}$, the energies of the saturable inductors, $L_{r 1}$ and $L_{r 2}$, are transferred to the load through the diodes, $\mathrm{D}_{\mathrm{a} 1}$ and $\mathrm{D}_{\mathrm{a} 2}$, until the inductor current of $L_{r 1}$ is reduced to zero. The shape of the current, , $i_{r 1}$, is shown during mode 3 in Figure 3.

(5) Mode $4\left(t_{4 b}-t_{5}\right)$ : Because $S_{a}$ is triggered off, the main switch, $S_{m}$, is completely on at $t_{4 b}$ in Figure 2(d). This mode is the same as the powering mode of the conventional PWM converter.

(6) Mode $5\left(t_{5}-t_{6}\right)$ : When the main switch, $S_{m}$, is turned off at $t_{5}$, the slope of the voltage for the main switch is determined by capacitance $C_{r}$. The slope is:

$$
\frac{d v_{s m}}{d t}=\frac{I_{\mathrm{L}}}{C_{r}}
$$

In equation (4), the turn-off slope of the main diode depends on the capacitance, $C_{r}$, and the load current, $I_{\mathrm{L}}$. Therefore we can design the slope by determining $C_{r}$. One switching cycle of the PWM operation is completed from modes 0 to 5 , and the next cycle is repeated by the same processes.

\section{Proposed Converter Characteristics}

Based on the analysis of the switch modes, the switching conditions of the switches are summarized in Table 1.

\subsection{Main Switch $S_{m}$ and Main Diode $D_{m}$}

The main switch, $\mathrm{S}_{\mathrm{m}}$, turns on at zero current by overlapping on times of $\mathrm{S}_{\mathrm{m}}$ and $\mathrm{S}_{\mathrm{a}}$, and turns off at zero voltage with the slope of equation (3), respectively. The main diode, $\mathrm{D}_{\mathrm{m}}$, turns off at zero current of $i_{r 2}$ with the slope of equation (2), and it turns on at zero voltage with the slope of equation (4), respectively. The reverse recovery current of the main diode, $\mathrm{D}_{\mathrm{m}}$, is limited by the slope of equation (2). Therefore, soft switching of the main switches is realized, as summarized in Table 1.

Table 1. Switching Conditions of the Switches

\begin{tabular}{cll}
\hline Switches & $\begin{array}{l}\text { Turn-on } \\
\text { conditions }\end{array}$ & $\begin{array}{l}\text { Turn-off } \\
\text { conditions }\end{array}$ \\
\hline $\mathrm{S}_{\mathrm{m}}$ & Zero current & Zero voltage \\
$\mathrm{S}_{\mathrm{a}}$ & Zero current & Zero voltage \\
$\mathrm{D}_{\mathrm{m}}$ & Zero voltage & Zero current \\
$\mathrm{D}_{\mathrm{a} 1}$ & Zero voltage & Zero current \\
$\mathrm{D}_{\mathrm{a} 2}$ & Zero voltage & Zero current \\
\hline
\end{tabular}

\subsection{Auxiliary Switch $S_{a}$ and Diodes $D_{\mathrm{a} 1}, D_{\mathrm{a} 2}$}

The auxiliary switch, $\mathrm{S}_{\mathrm{a}}$, satisfies a zero-current turn-on with the slope of equation (1), and a zero-voltage turn-off with the slope of equation (3). The auxiliary diode, $\mathrm{D}_{\mathrm{a} 1}$, is turned on at zero voltage at time $t_{2}$, and $D_{a 2}$ is turned on at zero voltage at time $t_{3}$. The two diodes are simultaneously turned off with the satisfying zero-current condition with the slope of equation (2). This means that the reverse recovery currents of the two diodes are limited by the slope of equation (2). Therefore, soft switching of the auxiliary switches is additionally realized, as summarized in Table 1. 


\subsection{Minimization of Conduction Loss}

Because the main switch, $S_{m}$, turns on at time $t_{2}$ before the resonant operation [8], no resonant operation exists between the saturable inductors and internal capacitance of the main switch. Therefore, the turn-on period of $S_{a}$ can be minimized. The effective turn-on period is only $t_{1 b}-t_{2}$ during mode 1 because the current for $t_{1 a}-t_{1 b}$ is very low. Figure 4 represents the effective on time of the auxiliary switch, $S_{a}$, in a comparison of the proposed type with the conventional type [8]. As shown in Figure 4(a), the effective turn-on time of $\mathrm{S}_{\mathrm{a}}$ is dramatically reduced by emitting the resonant operation. In Figure 4(b), the conduction time of $S_{a}$, is extended by the internal capacitor of the main switch and time $t_{r}$, which is half the resonant period on account of the resonant operation for the saturable inductor, $L_{r 2}$,

By eliminating the resonant operation, the zero-voltage turn-on of the main switch, $\mathrm{S}_{\mathrm{m}}$, must be sacrificed. However, the zero-current turn-on of the main switch, $\mathrm{S}_{\mathrm{m}}$, should nevertheless be operated by overlapping the times of switches $S_{m}$ and $S_{a}$,. The relatively low voltage operation of the converter due to the reduction of the conduction time for auxiliary switch $\mathrm{S}_{\mathrm{a}}$ is more important for reducing the loss.

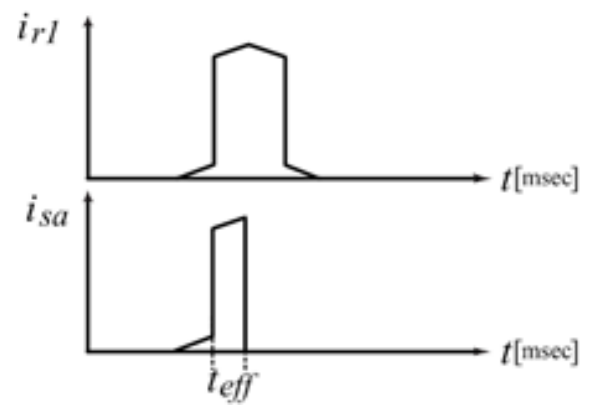

(a)

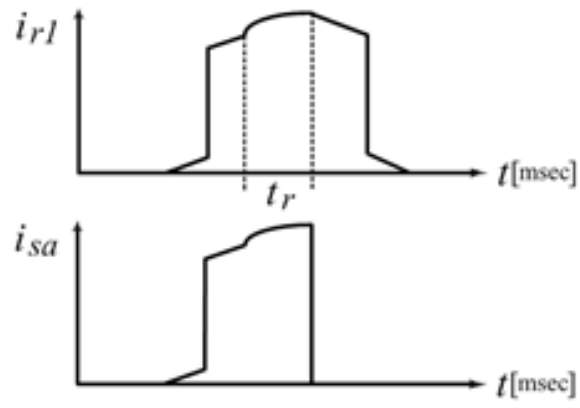

(b)

\section{Figure 4. Effective On-Time of Auxiliary Switch $S_{a}$, in a Comparison of} the (a) Proposed Converter and (b) Conventional Converter

\section{Family of Soft-Switched PWM Converters}

To generalize the PWM converter to soft-switched converters, which minimize the on-time of the auxiliary switch, two types of cells are suggested. Figure 5(a) shows cell type 1, which can be applied to the converter when the cathode of the main diode is connected to the highest voltage of the circuit such as a boost converter.

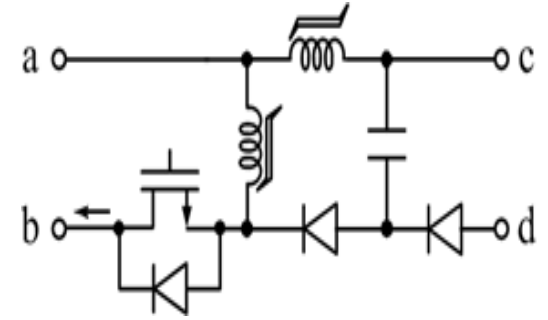

(a)

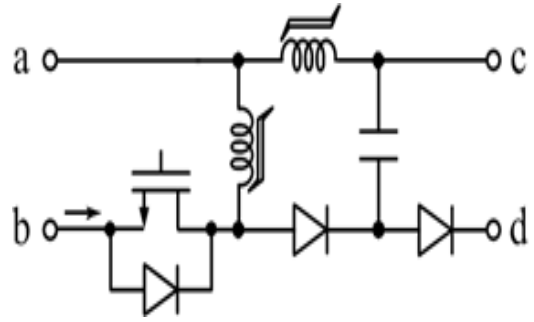

(b)

Figure 5. Proposed Cell Type for Generalization of the Converter: (a) Cell Type 1; (b) Cell Type 2.

Figure 5(b) shows cell type 2, which can be applied to converters when the anode of the main diode is connected to the lowest voltage of the circuit, such as in the singleended primary inductance converter (SEPIC) and buck, buck-boost, Cuk, and zeta converters. The connection methods of each cell are summarized in Table 2. As shown in 
the table, we can also select $\mathrm{N}$-channel metal-oxide semiconductor field-effect transistors (MOSFETs) when they are more convenient to implement.

By applying the auxiliary cells to the converters, we can generate a family of softswitched PWM converters with the minimized on-time of the auxiliary switch. The family has buck, boost, buck-boost, Cuk, SEPIC, and zeta converters. As shown in Figure 6, the Cuk and SEPIC converters have P-channel power MOSFETs for convenient implementation. However, we can additionally use N-channel power MOSFETs for the Cuk and SEPIC converters.

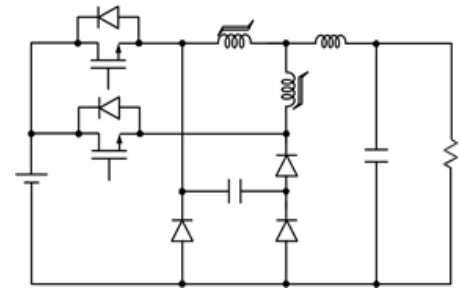

(a)

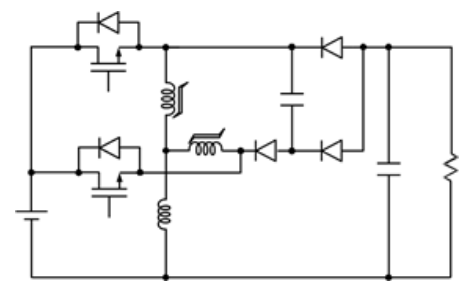

(a)

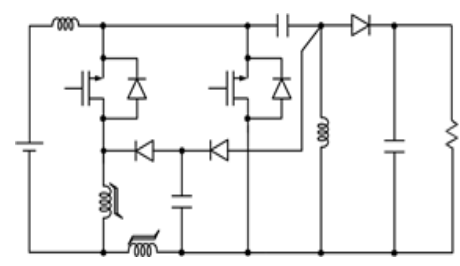

(e)

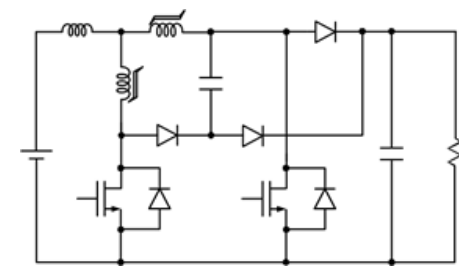

(b)

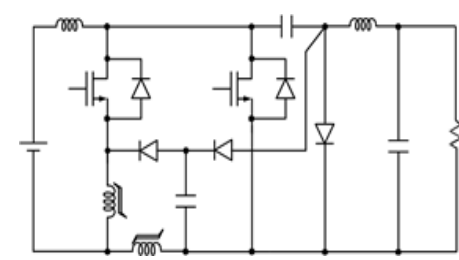

(d)

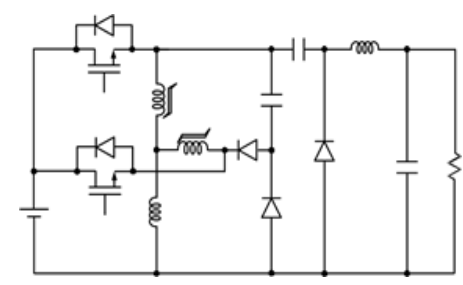

(f)

Figure 6. General Converter Topologies: (a) Buck; (b) Boost (c) Buck-Boost; (d) Cuk; (e) SEPIC; (f) Zeta.

Table 2. Soft Switching Cell Types.

\begin{tabular}{|c|c|c|}
\hline Cell type & Cell type 1 & Cell type 2 \\
\hline $\begin{array}{l}\text { Main diode } \\
\text { connection }\end{array}$ & $\begin{array}{l}\text { Cathode of main diode is connected to highest } \\
\text { voltage position for applying circuit }\end{array}$ & $\begin{array}{l}\text { Anode of main diode is connected to lowest voltage } \\
\text { position for applying circuit }\end{array}$ \\
\hline a & Serial connection at inductor & Serial connection at inductor \\
\hline $\mathrm{b}$ & $\begin{array}{l}\text { Connected at drain when main switch is N-channel } \\
\text { MOSFET, and at source when main switch is P- } \\
\text { channel MOSFET }\end{array}$ & $\begin{array}{l}\text { Connected at drain when main switch is N-channel } \\
\text { MOSFET, and at source when main switch is } \mathrm{P} \text { - } \\
\text { channel MOSFET }\end{array}$ \\
\hline & Connected at cathode of main diode & Connected at anode of main diode \\
\hline $\begin{array}{l}\mathrm{c} \\
\mathrm{d}\end{array}$ & $\begin{array}{l}\text { Connected at source when main switch is } \mathrm{N}- \\
\text { channel MOSFET, and at drain when main switch } \\
\text { is P-channel MOSFET }\end{array}$ & $\begin{array}{l}\text { Connected at source when main switch is } \mathrm{N}- \\
\text { channel MOSFET, and at drain when main switch } \\
\text { is P-channel MOSFET }\end{array}$ \\
\hline
\end{tabular}

The converters in the family shown in Figure 6 have almost the same characteristics as the boost-type converter, which is discussed above. Their key waveforms are also similar to those of the boost-type converter. 


\section{Experimental Results}

For the experimental verification of soft-switching characteristics and minimization of conduction loss of the auxiliary switch, the prototype circuit of Figure 1 was implemented, as shown in Figure 7. In the figure, the converter operates at $250 \mathrm{kHz}$ and a duty ratio of 0.5 . Additionally, the capacitance of $C_{r}$ is designed by $4.7 \mathrm{nF}$. In this condition, the voltage slopes of the main and auxiliary switches are limited by $100 \mathrm{~V}$ per $100 \mathrm{nsec}$.

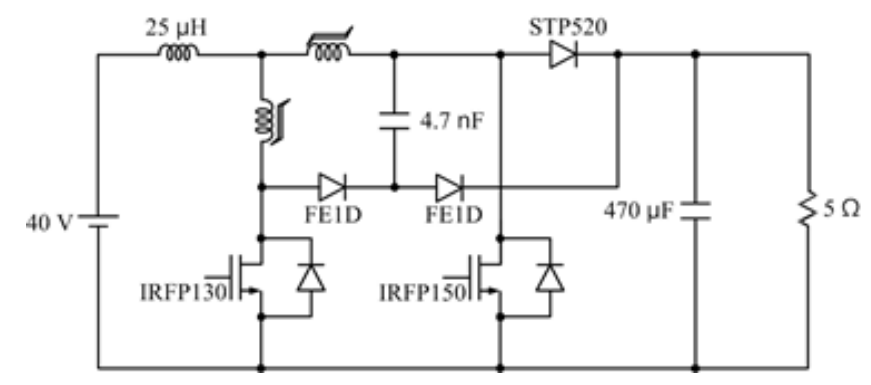

Figure 7. General topologies of the converter

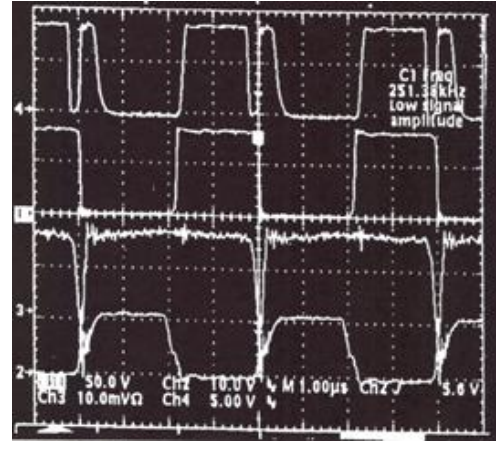

(a)

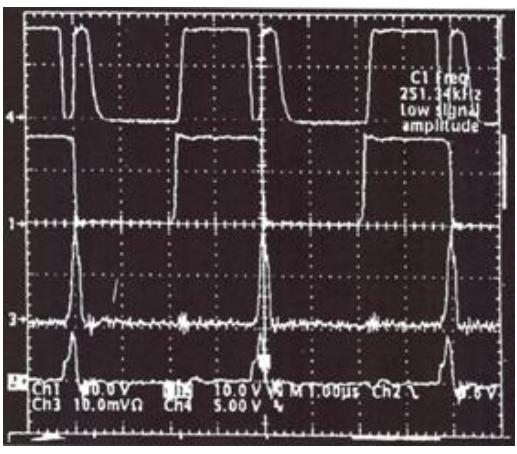

(b)

Figure 8. Converter Waveform: (a) First Trace, $v_{s a}: 50 \mathrm{~V} / \mathrm{div}$; Second Trace, $v_{s m}: 50 \mathrm{~V} / \mathrm{div}$; Third Trace, $i_{r 1}: 5 \mathrm{~A} / \mathrm{div}$, and Fourth Trace, $v_{g a}: 10 \mathrm{~V} / \mathrm{div}$. (b) First Trace, $v_{s a}: 50 \mathrm{~V} / \mathrm{div}$; Second Trace, $v_{s m}: 50 \mathrm{~V} / \mathrm{div}$; Third Trace, $i_{r 2}$ : $5 \mathrm{~A} / \mathrm{div}$, and Fourth Trace, $v_{g m}: 10 \mathrm{~V} / \mathrm{div}$.

Figure 8 shows the waveform of the converter. Figure 8(a) shows $v_{s a}, v_{s m}, i_{r 1}$ and gate signal $v_{g a}$. Figure $8(\mathrm{~b})$ represents $v_{s a}, v_{s m},, i_{r 2}$ and gate signal $v_{g m}$. Figure 8 shows that the main and auxiliary switches are softly turned on and off and the width of $i_{r 1}$ is as low as approximately $200 \mathrm{nsec}$. The effective turn-on period of auxiliary switch $\mathrm{S}_{\mathrm{a}}$ is dramatically reduced to approximately $100 \mathrm{nsec}$. Therefore, the effective turn-on period of $S_{a}$ can be reduced to as low as $1 / 20$ for the total turn-on period of the main switch for the half-duty ratio.

Figure 9 represents the efficiency curves as a function of output power. The efficiency is above $95.5 \%$ from 150 to $250 \mathrm{~W}$ load. Furthermore, it is always higher than $94.5 \%$ from 100 to $300 \mathrm{~W}$ load. In this experiment, the small saturation current inductor, $L_{r 1}$ is was inserted instead of a relatively larger saturable inductance [8]. This is another contributing factor for the increasing efficiency of the converter. In this application, a spike killer is the best solution for the saturable inductor because it caused minimal heat during the experiment. 


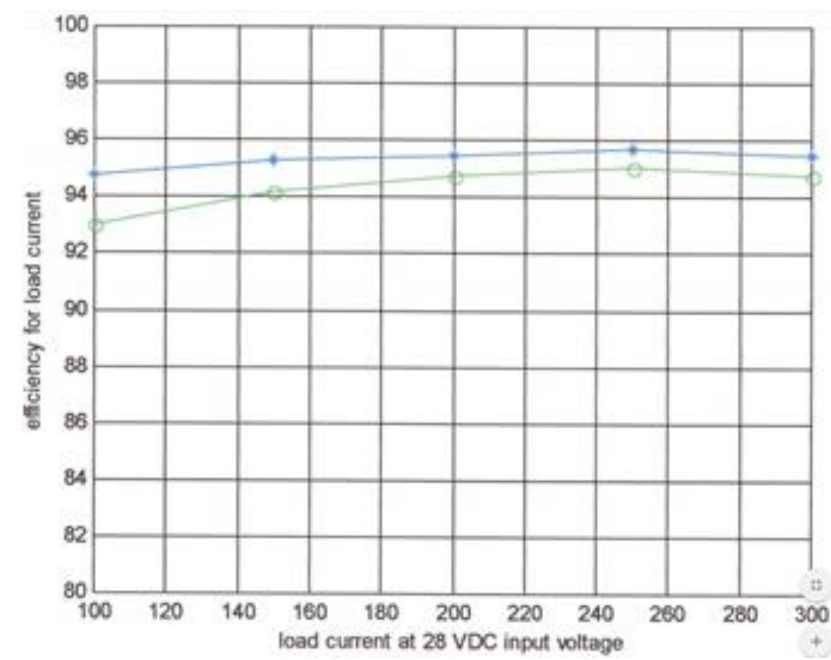

Figure 9. Efficiency for Load Current at 28 Voltage-Direct-Current (VDC) Input Voltage

\section{Conclusions}

In this paper we proposed a family of soft-switched PWM converters with main and auxiliary switches that turn on at zero current and off at zero voltage. The pulse width of the conduction period of the auxiliary switch is minimized in these converters. To generalize the converters, a family of two types of auxiliary cells was suggested. These have two saturable inductors, which are operated to reduce the reverse-recovery current of the diodes while satisfying the zero-current turn-on of the switches.

The soft switching and pulse-width reduction of the auxiliary switch were verified for a $250-\mathrm{kHz}$ operation of the boost-type converter. In this experiment, the two saturable inductors were operated to reduce the reverse-recovery current of the diodes while satisfying the zero-current turn-on of the switches, as mentioned above. Because no resonant operation existed, the pulse width of the conduction current could be reduced to $100 \mathrm{nsec}$. This width is approximately $1 / 20$ of the main switch for the half-duty ratio of the $250-\mathrm{kHz}$ operation.

\section{Acknowledgments}

This research was supported by the Ministry of Trade, Industry \& Energy(MOTIE), Korea Institute for Advancement of Technology(KIAT) through the Encouragement Program for The Industries of Economic Cooperation Region.

\section{References}

[1] D. M. Divan, "Diode as Pseudo Active Elements in High Frequency dc/dc Converter", IEEE trans. on Power Electronics, vol. PE-4, no. 1, (1989), pp. 8-14.

[2] N. H. Kutkut. "A New Dual-Bridge Soft Switching DC-DC Power Converter for High Power Application", IEEE Power Electronics Specialist Conference Rec., (1999).

[3] D. Y. Huh; H. S. Kim and G. H. Cho, "New Group of ZVS PWM Converters Operable on Constant Frequency and Its Application to Power Factor Correction Circuit", IEEE Power Electronics Specialist Conference Rec., (1992).

[4] M. J. Ryan, W. E. Brumsickle, D. M. Divan and R. D. Lorenz, "A New ZVS LCR - Resonant Push Pull Converter Topology”, IEEE Trans. on Industrial Applications, vol. 34, no. 5, (1998), pp. 1164-1174.

[5] J. K. Chung and G. H. Cho, "A New Soft Switched PWM Quisi-Resonant Converter with a Folding Snubber Network", IEEE Trans. on Industrial Electronics, vol. 49, no. 2, (2002), pp. 456-461.

[6] IEEE Trans. On IE., VolPower Electronics Specialist Conference Rec., (1992).

[7] V. G. Agelidis, G. Joos and P. D. Ziogas, "A Low Loss Full Bridge PWM DC-DC Converter Topologies", IEEE Power Electronics Specialist Conference Rec., (1993). 
[8] G. Hua, C. Leu and F. C. Lee, "Novel Zero-Voltage-Transition PWM Converters", IEEE Power Electronics Specialist Conference Rec., (1992).

[9] G. B. Joung, "New Soft Switched PWM Converter", IEEE Power Electronics Specialist Conference Rec., (1996).

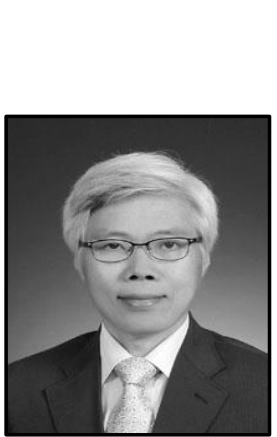

\section{Authors}

Gyu Bum Joung, received the B. S. degree in Electronics Engineering from Ajoum University, Korea in 1984. And he received the M. S. and Ph.D. degrees in electrical engineering from Korean Advanced Institute of Science and Technology, Korea, in 1986 and 1990 respectively. Since, he has been with Department of Energy Engineering, Woosuk University, Korea, where he is a professor. His interest research area is Power Electronics.

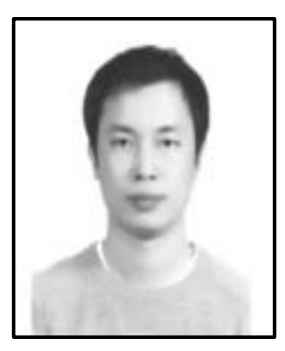

Zhiyong Dong, received the B. S. degree in Electrical and Electronics Engineering, Woosuk University, Korea in 2015. Since, he has been researched for Power Electronics as MS student in Woosuk University, Korea. His interest research area is Power Electronics.

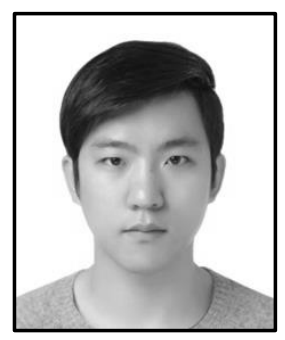

Sejong Hwang, received the B. S. degree in Electrical and Electronics Engineering, Woosuk University, Korea in 2015. Since, he has been researched for Power Electronics as MS student in Woosuk University, Korea. His interest research area is Power Electronics.

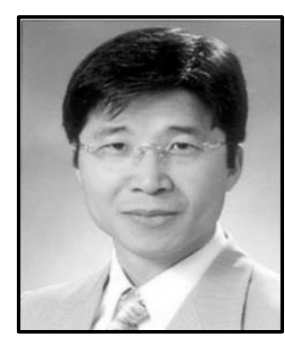

Dong-Gyu Jeong, received the B. S. degree in Electronics Engineering from YoungNam University, Korea in 1983. And he received the M. S. and Ph.D. degrees in electrical engineering from Korean Advanced Institute of Science and Technology, Korea, in 1986 and 1994 respectively. Since, he has been with Department of Electrical and Electronics Engineering, Woosuk University, Korea, where he is a professor. He had been the Vice President for the Korean Institute of Information Technology from 2013 to 2014. 